\section{Avian frugivory and seed dispersal of Indian Sandalwood Santalum album in Tamil Nadu, India}

\author{
P. Balasubramanian 1, R. Aruna 2, C. Anbarasu ${ }^{2}$ \\ \& E. Santhoshkumar ${ }^{2}$
}

1,2 Salim Ali Centre for Ornithology and Natural History, Anaikatty PO, Coimbatore, Tamil Nadu 641108, India Email: ${ }^{1}$ balusacon@yahoo.com (corresponding author)

Santalum album (Santalaceae) is a medium sized evergreen tree found in dry forest tracts of the Deccan Peninsula, where the major sandal growing tracts are located in Karnataka and Tamil Nadu. Sandal is also distributed in parts of Maharashtra, Andhra Pradesh and Kerala. The species was introduced to several areas of central and northern India, where it has naturalized and spread. It can grow up to an elevation of $1200 \mathrm{~m}$ and in rainfall zones of $300-3000 \mathrm{~mm}$. Flower panicles appear during December-April and fruiting occurs throughout the year (Matthew 1991). The fruit is a fleshy purplish-black globose drupe measuring approximately a centimetre in diameter. This species also regenerates from wood suckers. Viable seeds are produced after five years and dispersed by birds (Asian Regional Workshop 1998). Fire, grazing and exploitation of the wood for fine furniture, carving

Date of publication (online): 26 May 2011

Date of publication (print): 26 May 2011

ISSN 0974-7907 (online) | 0974-7893 (print)

Editor: Richard Thomas Corlett

Manuscript details:

Ms \# 02552

Received 27 August 2010

Final received 04 April 2011

Finally accepted 02 May 2011

Citation: Balasubramanian, P., R. Aruna, C. Anbarasu \& E. Santhoshkuma (2011). Avian frugivory and seed dispersal of Indian Sandalwood Santalum album in Tamil Nadu, India. Journal of Threatened Taxa 3(5): 1775-1777.

Copyright: (C) P. Balasubramanian, R. Aruna, C. Anbarasu \& E. Santhoshkumar 2011. Creative Commons Attribution 3.0 Unported License. JoTT allows unrestricted use of this article in any medium for non-profit purposes, reproduction and distribution by providing adequate credit to the authors and the source of publication.

Acknowledgements: We thank the Tamilnadu Forest Department for their support. Thanks are due to Dr. G Kumaravelu, IFS, former Additional PCCF, Mr. R.K. Ojha, IFS, Mr. H. Malleshappa, IFS and Mr. K. G. Anand Naik IFS for the encouragement. We are grateful to Dr. P.A. Azeez, Director, Salim Ali Centre for Ornithology and Natural History for the encouragement.

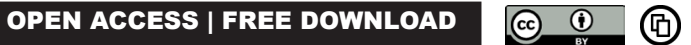

and oil are threatening the species (Asian Regional Workshop 1998). There is much concern

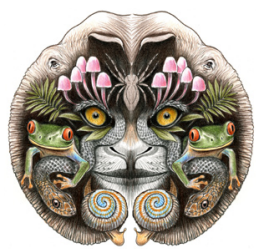
regarding over-exploitation due to smuggling for trade. Santalum album is a Vulnerable (IUCN 2010) and threatened species in southern India (Ravikumar et al. 2000).

Although known as a bird-dispersed species, very little information is available on frugivory and seed dispersal of S. album. Biotic dispersal consists of removal of plant propagules by animal frugivores and the deposition of seeds away from the source plant. The pulp of fleshy fruits, with the soft, edible, nutritious tissues surrounding the seeds is a primary food source for many animals, notably birds and mammals (Howe 1986). These animals regurgitate, defecate, spit out or otherwise drop the undamaged seeds away from the parent plants; they are the seed dispersers that establish a dynamic link between the fruiting plant and the seed-seedling bank in natural communities (Jordano 2000). Avian frugivores are considered as the most important seed dispersers in most ecosystems (Herrera 1995; Stiles 2000). Parrots, some pigeons and finches are seed predators (Corlett 1998). The study of interactions between avian frugivores and plant species is important for identifying the roles of individual disperser species play in plant recruitment dynamics, thus having implications for both theoretical understanding of mutualisms, species interactions and for applied work, including conservation and restoration (Jordano 1987; Loiselle \& Blake 1999). The present study was carried out to assess the role of different frugivores in the seed dissemination of sandalwood tree in Tamil Nadu.

\section{Materials and Methods}

Trees with ripe fruits were selected for field observations. A pair of binoculars was used by the observer, who sat near the tree, usually $10-15$ m away and watched the canopy for recording animal visits. Extended watches of 3-hr duration were made for a total of 54-hr in Anaikatty Hills, the Western Ghats and 24-hr in Pachaimalai Hills, the Eastern Ghats. During the extended watches, the observer noted the name of the visitor (bird/mammal), frequency of fruit-feeding visits by different species, and fruit handling behaviour (whether fruit ingested whole or 
only partly eaten and seeds dropped). The field study was carried out between 2006 and 2009 in Anaikatty hills $\left(11^{0} 5^{\prime}-11^{0} 31^{\prime} \mathrm{N} \& 76^{0} 39^{\prime}-76^{\circ} 47^{\prime} \mathrm{E}\right)$, the Western Ghats and Pachaimalai hills $\left(11^{\circ} 15^{\prime} \mathrm{N} \& 76^{\circ} 38^{\prime} \mathrm{E}\right)$, the Eastern Ghats in Tamil Nadu. Bird's names have been followed as per Ali (2002). Observations from Hasanur in Sathyamangalam Forest Division (11 ${ }^{\circ} 29^{\prime}$ $\left.11^{\circ} 48^{\prime} \mathrm{N} \& 76^{0} 50^{\prime}-77^{\circ} 27^{\prime} \mathrm{E}\right)$, the Eastern Ghats are also discussed. The forest type (Champion \& Seth 1968) of the study sites comprise of southern dry mixed deciduous forest $(5 \mathrm{~A} / \mathrm{C} 3)$. Predominant trees of the sites include Bauhinia racemosa, Santalum album, and Chloroxylon swietenia.

\section{Results and Discussion}

A total of 217 birds belonging to eight species visited Santalum album (Table 1) in Anaikatty Hills, Western Ghats. These included three species of bulbuls, Pycnonotus sp., Brahminy Starling Sturnus pagodarum, Common Myna Acridotheres tristis, Asian Koel Eudynamys scolopacea, White-headed Babbler Turdoides affinis and Small Green-Billed Malkoha Phaenicophaeus viridirostris. Highest proportion of feeding visits was contributed by Redwhiskered Bulbul, Pycnonotus jocosus (20.3\%) followed by White-headed Babbler (16.7\%) and Asian Koel (16.3\%). Among the various avian families, Pycnonotidae (bulbuls) made the majority of the visits (43.6\%) followed by Sturnidae (mynas) (21.6\%). Brown-headed Barbet Megalaima zeylanica was also found to be an important seed disperser in Parali Hills, the Western Ghats (Balasubramanian et al. 1998).
Among the birds, Asian Koel, Brown-headed Barbet, Mynas, Starlings and Indian Grey Hornbill swallowed the whole fruit. Most often, bulbuls ate the fruit in piecemeal and dropped the seeds under the canopy itself. Occasionally, small fruits were swallowed by them.

In the Pachaimalai Hills, 349 birds belonging to three species visited the focal tree during the study period. Among the frugivorous birds, the highest proportion of visits was made by the Asian Koel (50.4\%) followed by Common Myna (38.6\%), and Rose-ringed Parakeet Psittacula krameri (11\%). In addition to birds, Three-striped Palm Squirrel Funambulus palmarum also visited the plant to eat fruit. While koel and myna consumed the whole fruit, parakeets ate the seeds. Three-striped Squirrel ate the pulp and dropped the seeds.

In the Sathyamangalam Forest Division, Balasubramanian \& Santhoshkumar (2009) observed Indian Grey Hornbill Ocyceros birostris playing an important role in the seed dispersal of S. album. The Indian Grey Hornbill's diet comprised a reasonable proportion of Santalum album fruits both in breeding season (7\%) and non-breeding season (4\%). Role of Indian Grey Hornbill in regeneration of S. album was evidenced by the presence of sandalwood seedlings in hornbill's nest middens. Three percent of the seedlings in hornbill middens comprised of S. album.

Birds constituted the principal seed dispersers of Santalum album. Except squirrels no other mammals were foraging on S.album fruit crops during this study. Most of the natural seedlings of sandal were found

Table 1. Avian seed dispersers of Santalum album at Anaikatty, Parali (Western Ghats), Hasanur, Pachaimalai (Eastern Ghats)

\begin{tabular}{|l|l|c|c|l|}
\hline \multirow{2}{*}{ Common Name } & \multirow{2}{*}{ Scientific Name } & \multicolumn{2}{|l|}{ Feeding visits } & \multirow{2}{*}{ Locations } \\
\cline { 2 - 4 } & & $\#$ & $\%$ & \\
\hline Red-vented Bulbul & Pycnonotus cafer & 28 & 12.90 & Anaikatty \\
\hline Red-whiskered Bulbul & Pycnonotus jocosus & 36 & 16.59 & Anaikatty \\
\hline White-browed Bulbul & Pycnonotus luteolus & 25 & 11.52 & Anaikatty \\
\hline Common Myna & Acridotheres tristis & 28 & 12.90 & Anaikatty, Pachaimalai \\
\hline Brahminy Starling & Sturnus pagodarum & 21 & 9.68 & Anaikatty \\
\hline Asian Koel & Eudynamys scolopacea & 37 & 17.05 & Anaikatty, Pachaimalai \\
\hline White-headed Babbler & Turdoides affinis & 38 & 17.51 & Anaikatty \\
\hline Small Green-billed Malkoha & Phaenicophaeus viridirostris & 4 & 1.84 & Anaikatty \\
\hline Brown-headed Barbet & Megalaima zeylanica & - & - & Parali Hills \\
\hline Indian Grey Hornbill & Ocyceros birostris & - & - & Hasanur \\
\hline
\end{tabular}


growing in the middle of thorny bushes, where the birds seem to have dropped the seeds. Birds that are beneficial to sandalwood dispersal and regeneration were Koel, Common Myna, Brahminy Starling, Brown-headed Barbet, White-headed Babbler and Indian Grey Hornbill. These species visited the fruit crop more frequently and swallowed the fruit wholly. Hence, these species could be considered as major seed dispersers. Asian Koel seems to have preference to sandal fruits. Bulbuls could not swallow the whole fruit, due to their smaller beak and narrow gape. They appear to play a minor role only. Parakeets did not play any role in seed dispersal. They consumed the fruits mainly to digest the seeds and hence considered as seed predators. Green-billed Malkoha made very few visits, thus contributing only a minor role.

Sustaining the Asian Koel population will ensure the regeneration of sandal trees in the forests. Efforts need to be undertaken to provide a healthy habitat for the seed dispersing bird species such as koel, as the population of Sandalwood tree is drastically dwindling in the wild.

\section{REFERENCES}

Ali, S. (2002). The Book of Indian Birds, $13^{\text {th }}$ Edition, Oxford University Press, Oxford, 326pp.

Asian Regional Workshop (1998). Conservation and Sustainable Management of Trees, Vietnam: Santalum album. In: IUCN 2010. IUCN Redlist of Threatened Species. Version 2010.2. www.iucnredlist.org.

Balasubramanian, P., S.N. Prasad \& K. Kandavel (1998). Role of birds in seed dispersal and natural regeneration of forest plants in Tamil Nadu, Technical Report 7, Salim Ali Centre for Ornithology and Natural History, Coimbatore, India, 43pp
Balasubramanian, P. \& E. Santhoshkumar (2009). Final Report of the Ecology of Indian Grey Hornbill, Ocyceros birostris with special reference to its role in seed dispersal in southern Eastern Ghats, Salim Ali Centre for Ornithology and Natural History, Coimbatore, India, 74pp.

Champion, H.G. \& R. Seth (1968). A revised survey of the forest types of India, Managers Publications, New Delhi.

Corlett, R.T. (1998). Frugivory and seed dispersal by vertebrates in the Oriental (Indomalayan) region. Biological Review 73: 413-448.

Herrera, C.M. (1995). Plant-vertebrate seed dispersal systems in the Mediterranean: Ecological, Evolutionary, and Historical Determinants. Annual Review of Ecology and Systematics 26: 705-27.

Howe, H.F. (1986). Seed dispersal by fruit eating birds and mammals, pp. 123-190. In: Murray, D.R. (ed.). Seed Dispersal. Academic Press, Sydney, Australia.

IUCN (2010). Santalum album (Sandalwood), IUCN Redlist of Threatened Species. Version 2010.2. www.iucnredlist.org.

Loiselle, B.A., \& J.G. Blake (1999). Dispersal of melastome seeds by fruit-eating birds of tropical forest understory. Ecology 80: 330-336.

Jordano, P. (1987). Patterns of mutualistic interactions in pollination and seed dispersal: connectance, dependence asymmetries, and coevolution. American Naturalist 129: 657-677.

Jordano, P. (2000). Fruits and frugivory, In: Fenner, M (ed.) Seeds: the ecology of regeneration in plant communities, $2^{\text {nd }}$ Edition. CABI Publications, Wallingford, UK, 125-166pp.

Matthew, K.M. (1991). An Excursion Flora of Central Tamil Nadu, India. Oxford \& IBH Publishing Co. Pvt. Ltd, New Delhi, 647pp.

Ravikumar, K., D.K. Ved, R.V. Sankar \& P.S. Udayan (2000). 100 Redlisted Medicinal Plants of Conservation Concern in south India, Foundation for Revitalization of Local Health Traditions, Bangalore, 76pp.

Stiles, E.W. (2000). Animals as seed dispersers, pp. 111-124. In: Fenner, M. (ed.). Seeds: The Ecology of Regeneration in Plant Communities. CABI, Wallingford, UK. 